\title{
動画像による個人識別技術を用いた勤急管理に関する研究
}

\section{Managing Time and Attendance Using Identification Technique with Film Images}

\author{
西田義 人 $^{\dagger}$ \\ 馬石 直 登 $^{\dagger}$,
}

\author{
田中成 典胡, \\ 北川 洋 平 ${ }^{\dagger}$,
}

古田均胡,
打尾賢一†

Yoshito Nishita $^{\dagger}$, Shigenori Tanaka ${ }^{\dagger \dagger}$, Hitoshi Furuta ${ }^{\dagger \dagger}$, Naoto Umaishi ${ }^{\dagger}$, Youhei Kitagawa ${ }^{\dagger}$ and Kenichi $\mathrm{Uchio}^{\dagger}$

\begin{abstract}
Recently, the way to manage working hours has become an issue with the increase in the death rate from overwork. The Labor Standards Law doesn't provide the way to manage working hours, though it makes it obligatory to manage working hours. In general, it is impossible to strictly manage working hours because a worker manually manages his/her own working hours. Therefore, biometric authentication technology using face images is receiving attention. However, the existing technology using face images is unsuitable for time and attendance management because it requires the person to turn his/her face to the camera, taking time and effort. Therefore, we propose a method of managing time and attendance of workers without making the person conscious of the camera. In this research, firstly we extracted a frontal face image by tracking the face in a film. We then identified the individual using the frontal face image. Finally we output time and attendance information for each individual based on the result of identification.
\end{abstract}

キーワード：勤总管埋，動画像，顔画像，バイオメトリクス認訨技術，個人識別

\section{1.まえがき}

近年，わが国では，テレビやニュースで取り上げられて いる過労による死亡率の増加に伴い, 労働時間の管理方法 が閣題 ${ }^{1)}$ となってきた。労働に関する諸条件を規定してい る労働基準法では, 労働時間の把握が義務づけられている が，把握方法については，客観的な記録を基礎として確認 し，記録することとしか定められて抢らず，厳密な把握方 法は規定されていない. 現状の勤怠管理の把握方法として は, タイムカードや出勤簿が主流であり, 各従業員に発行 したタイムカードを打刻させて出退勤データを登録し，そ のデータは，人手によってシステム等に入力される。しか し，このような場合，一人一人にタイムカードを発行する 必要がありロスが多くなる。また，システムにデー夕を入 力する必要があり, デー夕入力の際に入力ミス等が発生す るといった問題や人件費がかかるといった問題 ${ }^{2)}$ がある.

2009 年 4 月 1 日受付, 2009 年 7 月 21 口再受付, 2009 年 9 月 16 口採録 †関西大学 大学院 総合情報学研究科

（广 569-1095 高柣市霊仙寺町 2-1-1，072-690-3213）

†関西大学 総合情報学部

( ₹ 569-1095 高槻市霊仙寺町 2-1-1, 072-690-2153)

$\dagger$ Graduate School of Informatics, Kansai University

(2-1-1 Reizenji-cho, Takatsuki-city, Osaka, 569-1095 Japan)

†† Faculty of Informatics, Kansai University

(2-1-1 Reizenji-cho, Takatsuki-city, Osaka, 569-1095 Japan)
そこで，情報技術の発展に伴い，パソコンのログイン機 能を利用した勤意管理が利用されてきている。しかし，こ れらの方法では, 他人による操作が可能であるため, なり すまし等の問題が残る。なりすまし等の問題に対応するた めに，近年，バイオメトリクス認証技術を用いた入退室シ ステム等が提案 ${ }^{3) 4}$ さされている. バイオメトリクス認証と は，人間の生物学的な特徴を用いて自動的に個人を特定す る技術である。バイオメトリクス認証には，形状ベースと 動作ベースがある. 現在, バイオメトリクス認証で主流と なっているのは，形状ベースで，その主なものとして，指 紋，虹彩，血管，耳，手の形状や顔等を利用した認証 ${ }^{5) 6)}$ が 挙げられる，指紋を利用した認証では，指先の溝のパター ンを利用して認証を行う。虹彩を利用した認証では，曈の 周辺の黒目部分に沈着する脂肪のパターンを利用して認証 を行う。血管を利用した認証では，網膜，手の甲や手首等 の血管パターンを利用して認証を行う。耳を利用した認証 では, 耳の形状には強い個人性があることに着目して認訨 を行う．手の形状を利用した認証では，人間の手には指の 長さ，太さや手そのものの大きさなどの様々な特徴がある ことを利用して認証を行う。顔を利用した認証では，顔の 輪郭, 目・鼻の形状・配置, 肌の色分布を利用して認証を 行う.

その中でも，顔を利用した認証は，人問にとって最も自 
然な認証技術である．社員証や免許証等の個人を特定する ものには顔写真が貼付されているように，顔は個人を特定 するために最もよく利用されている．顔を利用した認証は， 他のバイオメトリクス認証と比較して以下のような利点 7)8) が挙げられる。

・既存の監視カメラを利用することが可能である.

・非接触な認証が可能である.

・離れた場所からの認証が可能である.

・被写体に負担をかけない認証が可能である.

・認識結果を人によって再確認することが可能である.

・なりすましの防止が可能である。

以上のように，識別の際に被与体に手間と負担をかけな い利点を持つことから，顔を利用した認証技術は個人識別 を行うために非常に有効な手法の一つである。ただし，既 存の顔識別技術 7) は，被写休が顔をカメラに向ける必要が ある. そのため, 被写体はカメラの前で立ち止まり, カメ ラを意識する必要があり, 精神的負担を受ける。

そこで, 本研究では, ディジタルビデオカメラで広域を 撮影し, 広い範囲で被写体の顔画像を抽出することで, 既 存システムのように, 被写体がカメラに顔を向けることな く被写体の識別を可能とし, 勤㤐管理に適応する. 本稿の 流れとしては，2 章では既存の顔画像を用いた個人識別技 術について述べる. 3 章では本研究で提案する勤点管理シ ステムの概要について，4章では本研究で提案する個人識 別の手法について述べる. そして, 5 章では, 提案手法の 実訨実験を行い, 本研究の有効性を示す.

\section{2. 既存の顔画像を用いた個人識別技術}

既存の顔識別技術は，正面顔画像を使用する場合が最も 識別精度が良いとされているが, 被写体がカメラの方向を 向く必要があるため, 被写体にストレスを与えるといった 問題点がある. しかし, 被写体がカメラを意識しない場合, 正面顔画像の取得が困難となり, 識別精度が著しく低下し てしまう。

既存の正面顔画像を利用した代表的な個人識別手法 ${ }^{8) 9)}$ には, 表 1 のよなものが挙げられる. その他にも, ニュー ラルネットワークやサポートベクターマシンを利用した手 法 ${ }^{9)}$ も提案されている. 一般的に顔の幾何学的特徴を用い た識別手法 ${ }^{10)}$ は, 顔器官間の距離を基に判定を行う。その ため, 高い解像度の顔画像が必要となる。また, 顔部品抽 出精度に識別精度が依存するため, 顔画像をパターンとす る手法と比較して精度が低いとされている。

一方, 顔画像をパターンとする手法において, 現在研究 されている手法は，ある一定の条件下では，ほぼ $100 \% に$ 近い精度が出る結果となっている. その中でも, 最も識別 精度が良いとされている手法としては, ガボールウェーブ レット変換とグラフ・マッチングを用いた手法 ${ }^{11)}$ や高次局
所自己相関特徵と線形判別分析を用いた手法 ${ }^{12)}$ が挙げら れる．各々の手法の特徴，メリットとデメリットを表 2 に 示す.

ガボールウェーブレット変換とグラフ・マッチングを用い た于:法は, 識別に利用する顔画像の解像度が低い場合, 顔 部品の取得精度が低下するため, 顔の位置合わせが困難と なる.また, この場合, 顔部品とその周辺の領域から個人 性を表す特徴量を算山することは困難である。このような 問題に対応する手法として, 識別の際に顔画像の位置あわ せを不要とし, 高い解像度の画像を必要としない特徵であ る高次局所自己相関特徵が有効である。しかし, 高次局所 自己相関特徴は，スケール変化に弱いといった問題がある.

本研究では，動画像を用いることで被写体がカメラを意 識することなく識別が可能な手法を提案する。.そこで, 目, 鼻や口等の顔部品が見えている顔画像を正面顔画像として, 識別の対象となる正面顔画像を動画像から自動で複数枚取 得し, 個人を識別する。そして, 動画像を利用するため撮 影された顔画像の解像度が低い場合でも, 識別が可能な高 次局所自己相関特徵と線形判別分析を用いた手法を使用し, 高次局所自己相関特徴のスケール変化に弱いという問題点 を解決するために高次局所自己相関特徴を拡張する。

\section{3. 研 究 の 概 要}

本研究では, 顔画像を用いて個人識別を行い, 識別結果 に基づき個人の勤点情報を出力するシステムの構築を目的 とする. 本システムでは, まず, 動画像中から複数枚の顔 領域画像を取得し, その中から正面顔画像を抽出する。次 に, 抽出した正面顔画像を用いて個人を識別する。最後に, 識別結果を基に個人の勤总情報を出力する．本システムの 特徵と機能を表 3 に示す.

\section{1 システムの構成}

本システムの構成を表 4 に示す. 本システムは, システ

表 1 代表的な個人識別手法

Major methods of identification.

\begin{tabular}{c|l|l}
\hline \hline 分類 & & \multicolumn{1}{c}{ チ法 } \\
\hline 画像パターン & 局所 & $\begin{array}{l}\text { ガボールウェーブレット変換とグラフ・マッチン } \\
\text { グを用いた手法 }\end{array}$ \\
\cline { 3 - 3 } & & Local Feature Analysis を用いた手法 \\
\cline { 3 - 4 } & \multirow{2}{*}{ 全体 } & 主成分分析による Eigenface 法を用いた手法 \\
\cline { 3 - 4 } & & $\begin{array}{l}\text { 高次局所白已相関特徴と線形判別分析を用いた } \\
\text { 手法 }\end{array}$ \\
\cline { 3 - 4 } & 部分空間法を用いた手法 \\
\hline 幾何学的特徵 & 顔部品の位置・顔部品間の距離を用いた手法 \\
\hline
\end{tabular}

表 2 既存手法の特徵・メリット・デメリット

Feature, merit and demerit of existing methods.

\begin{tabular}{|c|c|c|}
\hline 手法 & $\begin{array}{c}\text { ガホールウェーブレット変換と } \\
\text { グラフ・マッチングを用いた手法 }\end{array}$ & $\begin{array}{l}\text { 高次局所自己相関特徵と } \\
\text { 線形判別分析を用いたチ法 }\end{array}$ \\
\hline 特徵 & $\begin{array}{l}\text { 顔部品とその周辺の局所 } \\
\text { 的な領域を利用 }\end{array}$ & 顔画像全体を利用 \\
\hline メリット & 照明変化にロバスト & $\begin{array}{l}\text { パターンの平行移動に対 } \\
\text { してロバスト }\end{array}$ \\
\hline デメリット & $\begin{array}{l}\text { 顔の位置むわせが必要 } \\
\text { 計算時間がかかる }\end{array}$ & スケール変化に弱い \\
\hline
\end{tabular}




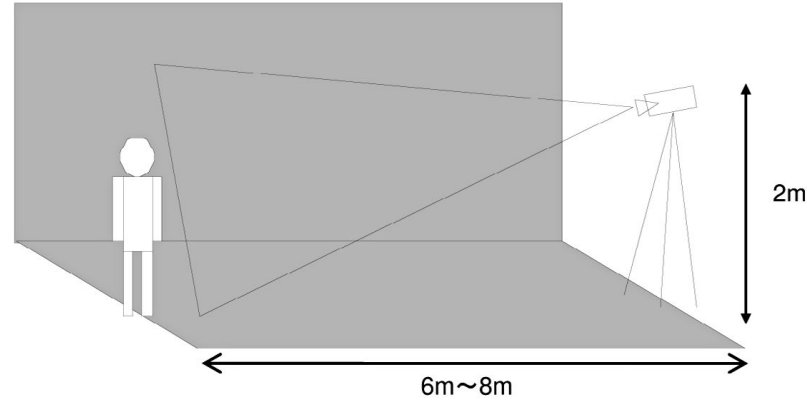

図 1 撮影条件

Condition of scene

ムを容易に構築するため，一般的なパソコンと画像入力用 のディジタルビデオカメラから構成される。また，勤念管 理システムは，入退室履歷を記録するためのものであるた め，個人識別による施錠解除のようにリアルタイムに識別 を行う必要はない。 そのため, 本システムは, オフライン システムとして構成する。

入力する動画像の撮影条件として，図 1 に示すように, 既存の監視カメラ等と同等の条件にするために，一般に市 販されているディジタルビデオカメラを三脚に固定して撮 影した。 カメラの設定場所は室内とし, 設置位置は地面か ら $2 \mathrm{~m}$ 程度に位置し, 撮影方向としては, 被写体は, カメ ラから $6 \mathrm{~m} \sim 8 \mathrm{~m}$ 離れた位置からカメラ方向に向かって移動 するものとした，なお，動画像中に同時に撮影される人物 は一人とした．また，本システムは，被写休がカメラに向 かって移動することを前提条件とするため, 勤总管理シス テムを構築する場合, 入室用と退室用の二つのカメラを使 用する必要がある。ただし，入室と退出は管理情報が異な るだけで識別処理は同じであるため, 本研究では一つのカ メラのみで実験を行った。

表 3 本研究の特徴と機能

Feature and function of present research.

\begin{tabular}{|c|c|}
\hline 特徵 & 被写体に負担をかけずに勤㤐情報を登録する。. \\
\hline & 正確な識別によるなりすましの防止が可能である. \\
\hline & 生体認証のためキー等を必要としない. \\
\hline & 勤急情報登録時の手作業を必要としない. \\
\hline 機能 & 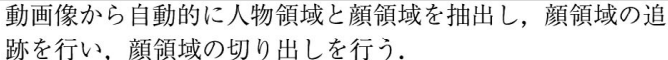 \\
\hline & パターン辞書に顔画像を教師データとして登録，更新と管理 \\
\hline & を行う。 \\
\hline & $\begin{array}{l}\text { 入力した顔画像を辞書に登録した顔画像パターンと比較し, } \\
\text { 個人識別を行う. }\end{array}$ \\
\hline
\end{tabular}

表 4 本システムの構成

System consititution.

\begin{tabular}{c|l}
\hline \hline パソコン & DELL 社製 OPTIPLEX GX620 \\
\hline CPU & Pentium4 3.4GHz \\
\hline メモリ & $3.5 \mathrm{~GB}$ \\
\hline ビデオカメラ & NV-GS200K-S \\
\hline ファイル形式 & AVI \\
\hline AVI コーデック & Indeo Video 5.0 \\
\hline フレームレート & 30 フレーム \\
\hline 動画サイズ & $640 \times 480$ pixel \\
\hline
\end{tabular}

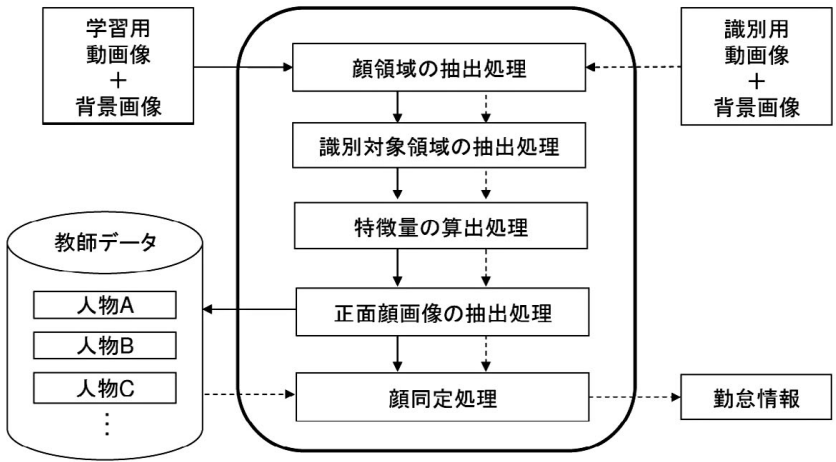

図 2 個人識別の流れ

Flow of identification technique.

\section{2 本研究における個人識別の流れ}

本システムに扔ける個人識別の流れを図 2 に示す．処理 は大きく分けて学習モードと識別モードの二つに分けられ る，学習モードでは，動画像から登録する人物の顔を倹出 し, 検出した顔画像から識別に必要な特徵を算出し, 名前 と特徵を教師データとして登録する。識別モードでは, 動 画像から勤怠管理の対象となる人物の顔を検出し, 検出し た顔画像から識別に必要な特徵を抽出し，教師データとの 比較を行う，比較の結果，対象となる人物が教師デー夕内 に存在する場合，図 3 に示すように，名前，出勤日，出勤 時間と識別対象となった被写体の顔画像の保存されている パスを勤怠情報として登録する。

顔領域の検出処理では，識別の対象となる人物の全身が 撮影されている動画像に対して，人物の身体的特徵と色情 報を使用し，顔領域を検出する。識別対象領域の抽出処理 では，検出した顔領域から識別に利用するための領域を抽 出する. 特徵量の算出処理では, 顔画像全体から識別に利 用する特徴量を算出する。正面顔画像の判定処理では，個 人識別に利用可能な正面顔画像かどうかを判定する．本研 究では, 証明写真のような正確な正面顔画像のみを抽出す るのではなく, 目, 鼻や口等の顔部品が見えている顔画像 も正面顔画像として抽出する。これは，個人識別の際に入 力対象の顔画像の正確な正面顔画像が抽出できない場合に 対応するためである，顔同定処理では，識別の対象となる 人物の正面顔画像として判定した顔画像の特徴量と予め登 録されている各人物の特徴量を比較することで，識別の対 象となる人物が誰であるかを判定し，勤念情報をシステム に登録する。

\section{4. 個 人 識 別}

\section{1 顔領域の検出処理}

本処理では，撮影した動画像から人物の顔領域を検出す る．既存の顔領域の検出手法では，顔である可能性のある 領域を顔候補とし，その領域から顔領域を特定することで 顔領域を検出 ${ }^{13)}$ する。 しかし，既存の顔領域の検出手法 では，検出時間がかかる上に顔領域を誤検出する可能性が 


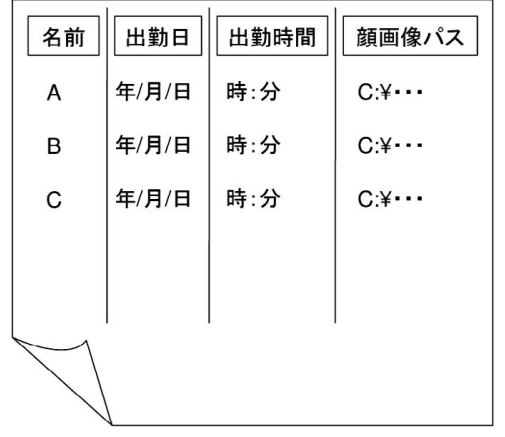

図 3 勤总管理情報

Information of time and attendance.

ある、本研究では, 撮影条件から被写体の体全体が動画像 に撮影されるため, 識別対象の全身が撮影されたフレーム において人物領域を抽出し, 人物領域から人物の身体的特 徵と色情報を利用して顔領域を検出する。 そして，以後の フレームでは, 前フレームで抽出した顔領域の追跡を行い, 顔領域を検出する。

人物領域の抽出では, 被写体の撮影された動画像と背景 画像を用いて, 背景差分を行い人物領域を抽出する. 背景 差分によって抽出された領域に対して, 大津の閾值法 ${ }^{14)} に$ よって䦐值を算出する。算出した閾値を基に, 動画像の各 フレームを 2 值化処理する. 2 值化処理によって算出され た領域に対してラベリングを行い, 領域の面積, 領域の縦 横比から人物領域を抽出する.

顔領域の検出では, 抽出した人物領域から人の頭は体の上 位 $1 / 8$ に存在するという身体的特徴を利用して顔候補領域 を抽出する. 顔候補領域に対して, 色情報を利用して肌色領 域を算出し, 顔領域を抽出する。肌色領域の算出は, RGB 色空間から $\mathrm{YCbCr}$ 色空間に変換し, 処理を行う. RGB色 空間から $\mathrm{YCbCr}$ 色空間への変換式 15) を次式に示す.

$$
\begin{aligned}
& Y=0.299 R+0.587 G+0.114 B \\
& C b=-0.172 R-0.339 G+0.511 B+128 \\
& C r=0.511 R-0.428 G-0.083 B+128
\end{aligned}
$$

なお，Yは輝度を表しており，Cb と $\mathrm{Cr}$ は色差を表してい る. Chai ら ${ }^{16)}$ は, YCbCr 色空間で照明変化に頑健な $\mathrm{Cb}$, $\mathrm{Cr}$ において，人の肌色は人種に依らず $\mathrm{Cb}$ と $\mathrm{Cr}$ の值が 77 $\leqq \mathrm{Cb} \leqq 127$ かつ $133 \leqq \mathrm{Cr} \leqq 173$ を満たすと述べている. 小柳ら ${ }^{17)}$ は, この閾值を利用して顔領域を検出している. 本研究は, 室内において勤点管理を行うことを目的として いるため，急激な照明変化は起こらないと考えられる。そ こで, 本研究においても, Chai らの手法を使用して人物の 顔検出を行う.

顔領域の追跡では，図 4 に示すように現在のフレームを $\mathrm{T}$ とすると $\mathrm{T}$ フレームと $\mathrm{T}+\mathrm{N}$ フレーム目に抒いて背景

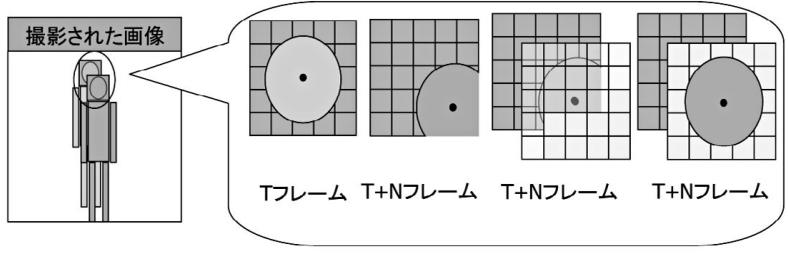

図 4 顔領域の追跡

Tracking of face area.

差分を行い矩形内に顔領域全体が含まれるように矩形を移 動する。

\section{2 識別対象領域の抽出処理}

検出した顔画像には，ノイズ等が含まれている場合や顔 以外の体の一部が含まれている場合がある。そこで, 本処 理では, 4.4 節の正面顔画像の判定処理と 4.5 節の顔同定処 理の対象となる顔領域の範囲を抽出する。しかし, 動画像 中から顔画像を検出した場合, 画像サイズが小さい場合が あるため, 顔部品を特定できないことがある，そこで, 顔 部品を利用してするのではなく, 肌色領域と顔領域のヒス トグラムを利用する。顔領域の範囲としては，上端は顔領 域の上部とし，下端は顎のラインに決定する. 左右端に関 しては, 顔領域の追跡で検出した領域をそのまま利用する. 顔のヒストグラムを図 5 に示す。肌色領域の横幅 $1 / 4$ か ら $3 / 4$ に限定した範囲で, 縦の濃淡值ヒストグラムを算出 する，算出したヒストグラムでは，鼻の濃淡值が最も高く, 鼻より下において， 口と顎が極小值を表している。このヒ ストグラムの特徵から顎のラインを算出し, 識別対象領域 を特定する．特定した領域において，本研究では顔領域以 外の背景領域には色情報を持たないものとする。すなわち， 顔領域の追跡で背景差分を行うことで取得した顔領域と特 定した識別対象領域のみの情報を保持する。しかし，常に このような特性を持ったヒストグラムが算出されるわけで はない．画像の大きさ等によってヒストグラムが複雑にな る場合や，輝度変化によってヒストグラムにノイズが混在 する場合がある。そこで，ヒストグラムが正確に算出され るように処理の際の画像サイズを一定にし, 輝度補正をか けることでノイズを抑制する. 輝度補正の手法としては, 線 形変換による輝度補正を行う。また，顔画像が一定サイズ 以下の場合，その顔画像は使用しない。 その理由としては， 画像サイズが小さすぎる場合, 個人を特定するための必要 十分の情報がないため, 識別に利用することができないと 考えられるからである。また，横幅に関しては，ヒストグ ラムを利用して限定する手法が存在するが，髪の影響等を 受けるため, 精度の良い検出が困難であり, また, 顔部品 を正確に取得することも困難であるため，限定しないこと とした。

\section{3 特徵量の算出処理}

本処理では, 識別対象領域の抽出処理で抽出した顔領域 から 4.4 節の正面顔画像の判定処理と 4.5 節の顔同定処理 


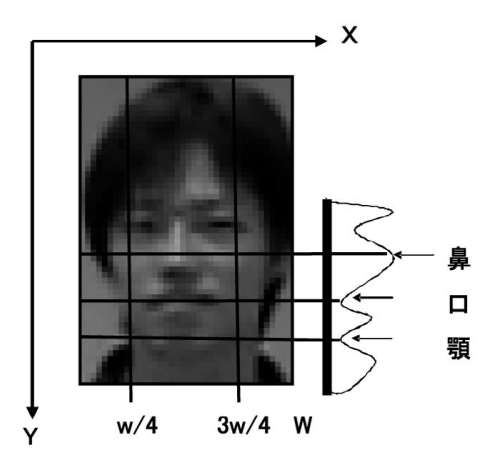

図 5 顔のヒストグラム Histogram of face.

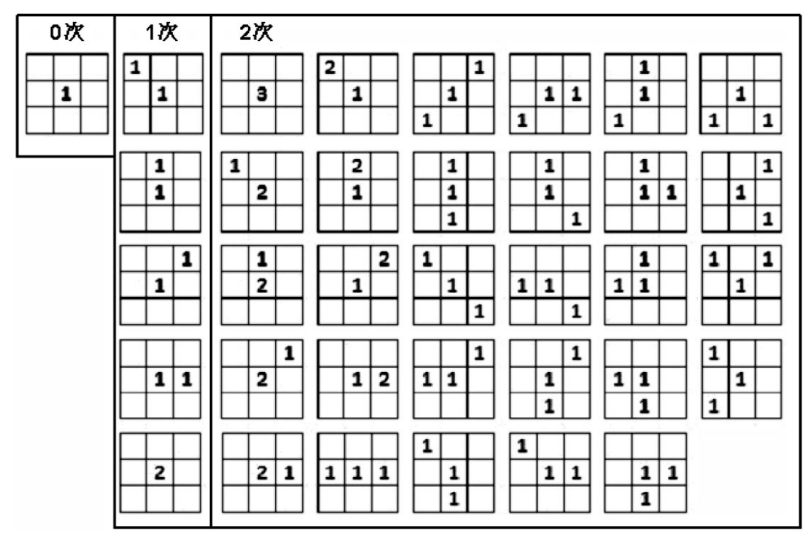

図 6 高次局所自己相関特徵

Higher-order local autocorrelation.

に利用するための特徵量を算出する，既存の個人識別では, 顔画像の画素值を特徵とする手法 ${ }^{7)}$, 目, 鼻や口等の顔部 㟧を特徴として利用する手法 ${ }^{10)}$ や顔画像に周波数変換を 行い振幅と位相を特徵とする手法 ${ }^{11)}$ が存在する。本研究 では，画像サイズが小さい場合があるため，先に述べた手 法では，個人の特性を表すのに充分な特徴を得ることが困 難である．また，識別の際に顔位置を合わせることが困難 である，そのため，画像の位置ずれに対する頑健性が必要 である，そこで，本研究では，画像から位置に関する不変 性を持つ特徵である高次局所自己相関特徴 ${ }^{18)}$ を利用する.

高次局所自己相関特徽では, 次数やマスクサイズを変え ることで無数のマスクパターンが考えられる．しかし，得 られる特徵の数が膨大になるため実用的ではない. そこで, 図 6 に示すように, 次数 $\mathrm{N}$ を 2 次までとし，マスクサイズ を注目画素の 8 近傍である $3 \times 3$ に制限する。この時，平 行移動による等価な特徴を除き, 重複した領域の選択を許 すと 35 個の特徴が得られる $(0$ 次: 1 個， 1 次: 5 個, 2 次： 29 個).この 35 個のマスクパターンから得られる特徵量 を識別に利用する。特徵量は, 高次局所自己相関特徵の各 マスクパターンを識別対象画像に対して走査し，マスクパ ターン毎に積分した值となる。 しかし, 高次局所自己相関 特徵は, $3 \times 3$ 画素の局所的な特徽を抽出するため, 顔領 域のスケールによっては，最適な特徵を抽出できない可能 性がある。そのため, 識別に利用するためには, 適切なス
ケールの顔画像に対して特徵を抽出する必要がある。

そこで, 本研究では, 解像度が異なる複数の画像を用い て, 高次局所自己相関特徴の手法を拡張した方法でスケー ルの変化に対応する．拡張した高次局所白已相関特徽を図 7 に示す。拡張した高次局所自己相関特徴は, 解像度の異 なる複数枚の画像に対して高次局所自己相関特徴を算出す る. 濃淡画像に対する高次局所自己相関特徵は, 35 次元で 表現されるのに対して, 本研究で拡張した高次局所白己相 関特徵は, 解像度の異なる画像を 3 パターン使用するため $35 \times 3$ の 105 次元で表現される. 解像度の異なる画像を使 用することで，対象の詳細な情報から大まかな情報までの 特徵量を抽出することが可能であり, 対象の平行移動に関 する不変性はこれらの特徵にも引き継がれるため, 識別に 有効な特徵量となる。

\section{4 正面顔画像の判定処理}

本処理では，検出した顔領域が正面顔画像かどうかを判 定する，その理由としては，個人識別では，正面を向いた顔 画像を利用した場合，最も良い精度が得られるためである。

既存の手法としては，顔の対称性を利用する手法，顔の 重心距離を利用する手法や主成分分析による手法等がある. これらの手法では, 顔部品の取得や正確な顔の位置を合わ せが必要である. しかし, 動画像中から検出される顔領域 は画像サイズが小さい場合があるため, 顔部品の取得や顔 の位置合わせが困難である，そこで, 本研究では, 顔部品 の取得や顔の位置合わせが不要で顔領域のサイズが小さい 場合でも，顔を判別することができる高次局所自己相関特 徵を用いて正面顔画像を判定する。なお，本処理では，顔 画像が証明写真のような止面顔画像であるかどうかを判定 するのではなく，識別に適さない顔画像を除去することが 目的である。

本研究で提案する正面顔画像の判定手法を図 8 と図 9 に 示す. 本処理の手順としては，まず，図 8 に示すように， 教師データから取得した 35 次元の特徴べクトル群に対し て主成分分析を行い，固有值と各固有值に対応する固有心゙ クトルを算出する。ここで，ノイズを削減するために算出 した固有值の中から固有值の高いもののみを使用し, 固有 空間を作成する。次に，図 9 に示すように，入力データと 教師データから取得した特徵ベクトルを固有空間上に射影 することにより, 正面顔画像の判定に適した特徵べクトル に変換する。そして，入力データと正面顔画像の教師デー 夕間のユークリッド距離 ${ }^{19)}$ を算出し, 閾値より小さい場 合, 正面顔画像と判定する. 本処理に扔ける教師データと は，複数人から取得した複数枚の止面顔画像である。ただ し, 本研究では, 抽出される顔領域の画像領域に占める割 合が常に一定になるとは限らない. そのため, 教師データ には，様々な割合の正面顔画像を用いる。

\section{5 顔同定処理}

(1) 教師デー夕の作成

顔同定処理で利用する教師デー夕は, 勤急管理の対象と 

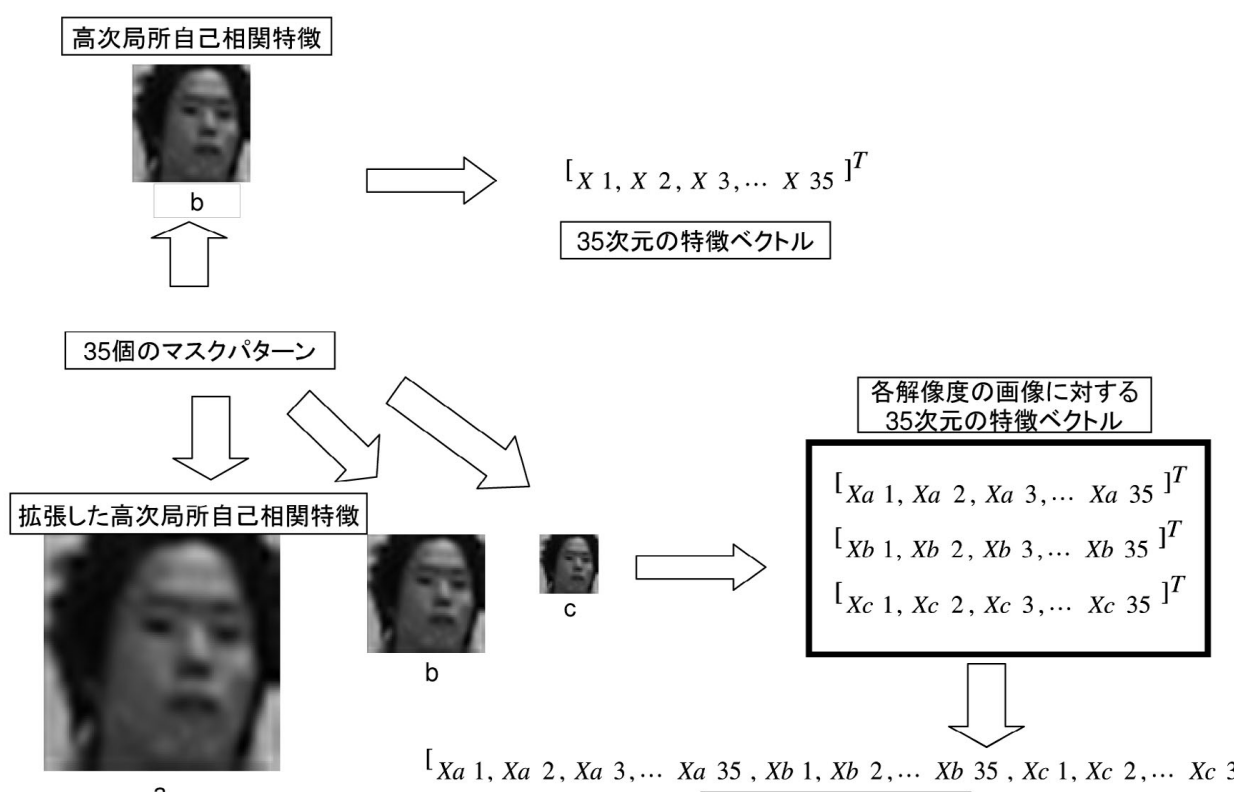

a

105次元の特徵ベクトル

図 7 拡張した高次局所自己相関特徴

Extension of higher-order local autocorrelation.

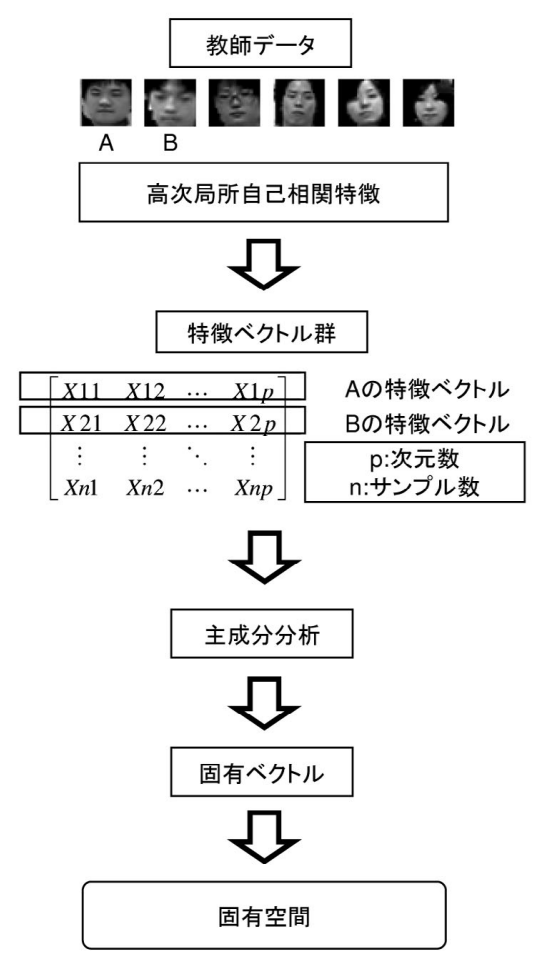

図 8 固有空間の作成方法 Method for making eigen space.

なる人物の正面顔画像から算出した 105 次元の高次局所自 己相関特徵とする. 顔同定処理では, 個人識別を行うため, 高い精度が必要とされる。そのため, 顔同定処理で使用す る入力データと教師データは拡張した高次局所自己相関特 徵を使用する. 特徵を抽出するための顔画像は, 動画像中 から 4.1 節〜 4.4 節の処理によって取得した正面顔画像とす る.たたし, 顔同定処理では, 勤㤐管理の対象となる被写 体が誰であるかを識別する必要があるため, 人物毎に特徴

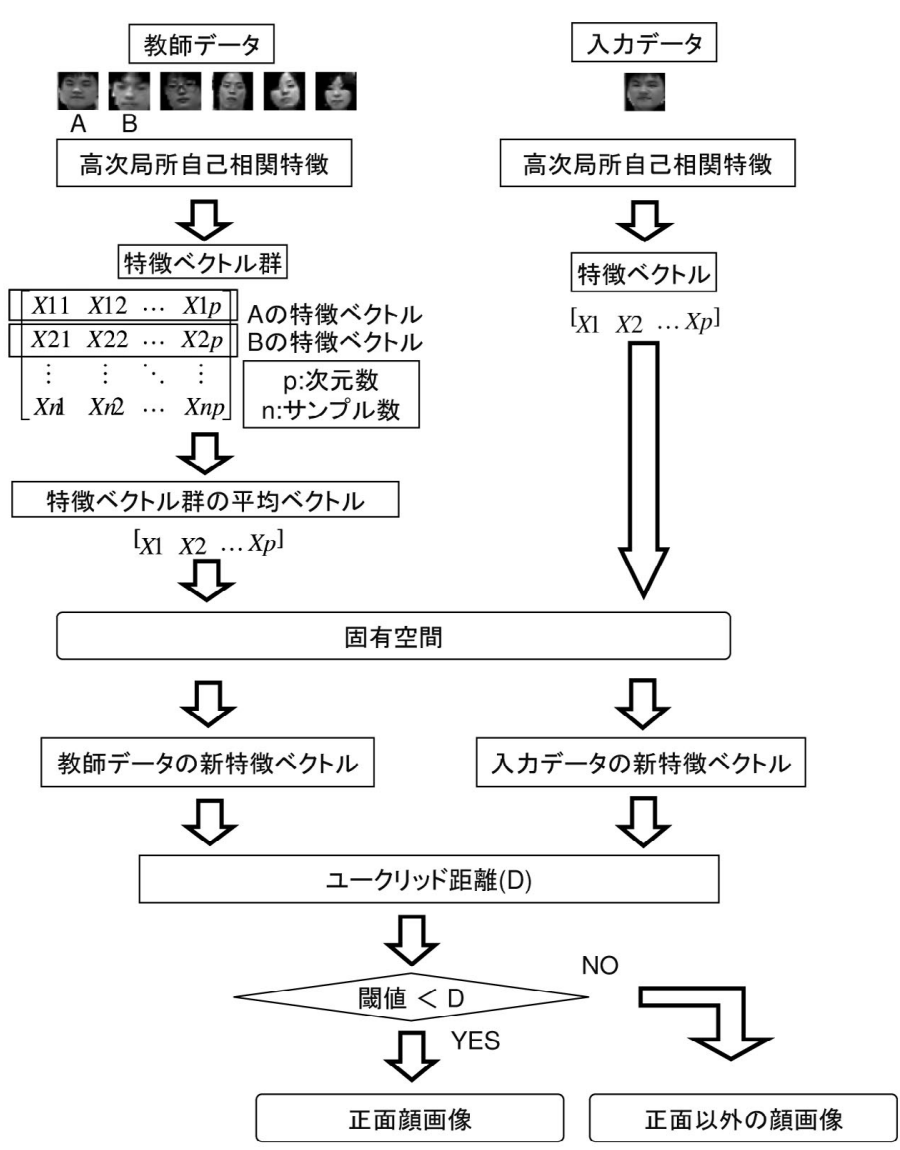

図 9 正面顔画像の判定手法

Method for extracting frontal face image.

量を登録する，また，本研究では，教師データに利用する 顔画像を入力動画像の撮影場所と同一場所で撮影すること により, 光量変化の問題に対応する. 光量変化は, 撮影す る場所によって，画像巾の異なる場所に影響を与える．光 


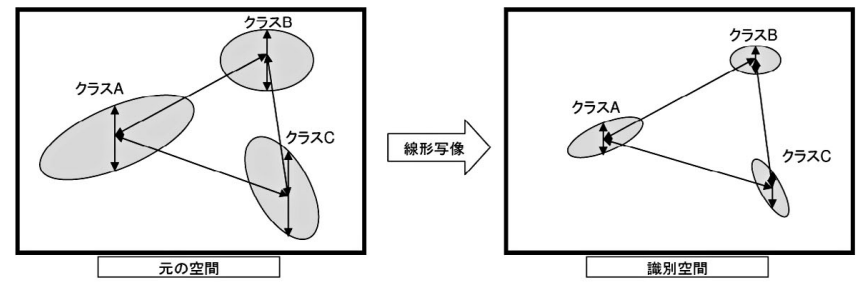

図 10 識別空間

Identification space.

量変化に対応する研究も多数行われているが, 現状完全に 解決することは難しい. そこで, 入力動画像と同様の場所 で，教師デー夕用の顔画像を作成することによって，同様 の光量変化の影響を受けることを利用する．また，本シス テムは, 室内での利用を前提としているため, 太陽光や天 候などの大きな光量変化はないものと考える.

(2) 顔同定

本処理では, 入力データと教師デー夕の顔画像から算出 した特徴量の比較を行い，入力データがどの人物であるか の判定を行う．本システムに扔ける同定手法は，搪張した 高次局所自己相関特徴と既存の線形判別分析によって識別 に適した特徴を算出し，マハラノビス距離 ${ }^{19)}$ によって類 似度を算出する. 高次局所自己相関特徵は, 顔部品の取得 や顔の位置合わせを行うことなく，個人の特徵を抽出する 基本的な特徴ではあるが, 特別識別に適した特徴ではない. そこで，算出した特徴量を線形判別分析 ${ }^{20)}$ を用いて，ク ラス間の距離が離れ，クラス内の距離が近くなるような特 徵量に变換する．線形判別分析による識別空間を図 10 に 示す. 線形判別分析では，教師データのクラス間共分散行 列とクラス内共分散行列から定義される識別基準を最大に することによって，教師データのクラスを識別するために 最適な係数行列を算出する。この際, 識別空間の次元数は $\min ($ クラス数 -1 , 次元数) となる. 算出した係数行列を 用いて教師データから識別空問を算出し，識別空問上に教 師データを射影する。

本研究では, 撮影条件から顔画像の解像度が変化するた め, 拡張した高次局所自己相関特徵を利用する. そして, 線 形判別分析を行うことで，個人識別に適した特徵に変換す る.しかし，入力画像を一枚のみ利用した識別では，利用 した画像が正確に抽出されていない場合や，輝度の影響に よる問題が発生した場合，誤判定される恐れがある．複数 枚の画像を利用した場合，その中の 1 枚に問題が発生した としても他の画像で影響の軽減が叮能となる。本研究では, 動画像中から勤急管理の対象となる複数枚の顔画像を取得 することが可能であるため, 複数枚の顔画像を利用して識 別を行う. 比較手法としては, 入力画像群から平均ベクト ルを算出し，教師データから算出した識別空間に射影する ことで, 入力データの新特徵ベクトルを算出する. その特 徵と教師データとのマハラノビス距離を算出する。 そして, 距離が最も近く, 閾值以上である場合, 入力データは, 距
離の最も近い人物と断定する。閾值に関しては, 実験の結 果から最適な数值を使用する。

\section{5. 実 験 と 評価}

本章では, 正面顔画像の判定率, 本研究の撮影環境にお ける個人識別の識別率, 既存研究の撮影環境における個人 識別の識別率, 本人拒否率 (FRR：False Rejection Rate) と他人受入率 (FAR：False Acceptance Rate) ${ }^{21)}$ に関する 四つの実験を行い，本研究で提案した手法が勤总管理の方 法として有効であることを検証する。

\section{1 正面顔画像の判定率}

本実験では，正面顔画像の判定処理の有効性を検証する ため, ディジタルビデオカメラで撮影した動画像から抽出 した被写体の顔領域に対して，本システムで正面顔画像の 判定を行い, その精度比較を行った. 実験内容としては, 本 システムの判定結果と目視で行った判定結果を比較した. なお，本実験では，顔部品である両目，鼻や口が見えてい る画像を正面顔画像とした，穴の理由として，本研究では， ディジタルビデオカメラで撮影した動画像中から自動的に 顔画像を検出するため, 証明写真のような正面顔画像が取 得できるとは限らない，そこで，本システムでは，多少の顔 の傾きのある顔画像も個人識別に使用するためである。ま た，本実験で使用した動画像には，15 人の人物が撮影され ており, 判定に使用した顔画像は, 動画像から抽出した正 面顔画像 500 枚と非正面顔画像 500 枚を使用した。

\section{(1) 実験結果}

本実験では，目視による実測結果とシステム上で算出し た結果を比較することにより，本システムの判定率を算出 した．表 5 では，正面顔画像をシステムで処理した場合の 精度と正面顔画像以外の顔画像をシステムで処理した場合 の精度の結果を示す．ここで，正常数とは，正面顔画像を 入力とした場合, 正面顔画像と判定された顔画像の枚数を, また，正面以外の顔画像を入力とした場合，正面顔画像と 判定されなかった顔画像の枚数を示す. 誤判定数とは, 正 面顔画像を入力とした場合，正面顔画像と判定されなかっ た顔画像の枚数を，また，正面以外の顔画像を入力した場 合，正面以外の顔画像と判定されなかった，つまり，正面 顔画像と判定された顔画像の枚数を示す.

\section{(2) 考 察}

正面顔画像の判定結果は表 5 に示すように, 正面顔画像に 対する判定率は, $91 \%$ の判定精度となり，概ね良好な結果 が得られた。しかし，正面以外の顔画像に対する判定率は，

表 5 本研究による正面顔画像の判定率

Decision rate of frontal face image in present research.

\begin{tabular}{c|r|r}
\hline \hline & 正面顔画像 & 正面以外の顔画像 \\
\hline フレーム数 & 500 枚 & 500 枚 \\
\hline 正常数 & 457 枚 & 375 枚 \\
\hline 誤判定数 & 43 枚 & 125 枚 \\
\hline 判定率 & $91 \%$ & $75 \%$ \\
\hline
\end{tabular}


$75 \%$ の判定精度となり, 誤判定を多く含む結果となった. 正面顔画像の誤判定の原因としては，教師データに含ま れない正面顔画像が, 正面以外の顔画像と判定されたため であると考えられる．例としては，首を傾げた顔画像や髪 で顔の一部が隠れた顔画像などが挙げられる。これらは, 正面顔画像の教師データのパターンを増やすことで, 正面 顔画像として抽出することが可能となると考えられる。 ま た, 正面以外の顔画像の誤判定としては, 顔の一部が切れ ている画像が挙げられる。 その原因は図 9 に示すように, 正面顔画像の判定処理では, 入力データと教師データ間の ユークリッド距離を算出し, その距離が閾值より小さい場 合, 正面顔画像と判定していることが挙げられる. 本研究 では, 個人識別に様々な顔画像パターンを利用したいため, 閾值を高く設定している，そのため，上記のような顔画像 が正面以外の顔画像と判定されなかったと考える。閾值を 低く設定することにより, 正面以外の顔画像の誤判定数を 少なくすることができるが, 正面顔画像の誤判定数が多く なる. 本研究では, 正面以外の顔画像の誤判定数を少なく するより, 正面顔画像の誤判定数を少なくする方が望まし いため, 閾値を低く設定することは適切ではないと考える.

\section{2 本研究の撮影環境における個人識別の識別率}

本実験では，ディジタルビデオカメラで撮影した動画像 から取得した正面顔画像を使用して，個人識別に関する実 証実験を行った。実験内容としては, 動画像から抽出した 複数枚の正面顔画像を入力データとし, 予め登録してある 教師データとの比較を行うことによって, 入力データの人 物の識別を行う. そして, 高次局所自己相関特徴と線形判 別分析を組合せた手法 ${ }^{5)}$ との精度比較を行うことで, 本研 究における手法の有効性を実証する。既存研究で使用する 教師デー夕は, 入力データとは異なる方法で作成している. しかし, 実際の環境で本システムを利用する場合, 顔画像 の大きさや画像中に占める顔領域の割合が一定になるとは 限らない。そのため, 本実証実験で使用する教師データは, 本システムに抢ける正面顔画像の判定処理で正面顔画像と 判定された顔画像を使用する。なお, 正面顔画像の判定精 度は, 5.1 節の実験の通りである。

本実験で使用した動画像には, 15 人の人物が撮影されて いるため, クラス数を 15 とし, 各クラスの識別精度を検 証した. また，入力データとして使用した正面顔画像の解 像度を 90 ピクセルに正規化し, 図 7 の b とした. そして, $\mathrm{b}$ を基準に $\mathrm{a}$ を 120 ピクセルに拡大し, c を 60 ピクセルに 縮小した. なお, 正規化の方法として, 縦幅を各ピクセル に変換した際の倍率を横幅に掛け合わせた。本実験でこれ らの解像度を使用した理由としては, 高次局所自己相関特 徵と線形判別分析を組合せた手法 ${ }^{12)}$ において, 顔画像の 解像度を 90 ピクセルとした場合に, 最も識別精度が良かっ たためである. そして, 各クラスの入力デー夕は, 本シス テムで取得した正面顔画像から 30 枚の画像を使用した.

\section{（1）実験結果}

本実験では，ディジタルビデオカメラで撮影した動画像 から抽出した正面顔画像を使用して，4.5 節の顔同定処理 の識別精度を検証した. 識別結果を表 6 に示す. 表 6 に示 すように各クラスの実験回数は 15 回として, 15 回の識別 率の平均值を識別正答率として算出した。 なお，抽出した 顔画像の特徴量の次元数は 105 次元であるが, 本実験では, クラス数が 15 であるため, 4.5 (2) 項で説明したとおり, 識 別に有效な特徵量の次元数は 14 となる. また, 入力データ と教師データの人数の增加に対する識別率の推移を比較す るために，15人から 30 人まで人数を増やし，人数毎に実 験を行った. 各クラスの実験回数は 5 回として識別正答率 を算出した．実験結果を表 7 に示す.

さらに，本研究における手法の有効性を確認するために 高次局所自己相関特徴と線形判別分析を組合せた手法 ${ }^{12)}$ との精度比較実験を行った。精度比較実験の結果を表 8 に 示す.

\section{（2）考察}

本研究では, 動画像を使用しているため, 既存の個人識 別で使用されている証明写真のような正面顔画像を取得す

表 6 識別結果

\begin{tabular}{c|r|r}
\multicolumn{3}{c}{ Result of identification. } \\
\hline クラス & 実験回数 & 識別正答率 \\
\hline No. 1 & 15 回 & $100 \%$ \\
\hline No. 2 & 15 回 & $100 \%$ \\
\hline No. 3 & 15 回 & $86 \%$ \\
\hline No. 4 & 15 回 & $100 \%$ \\
\hline No.5 & 15 回 & $100 \%$ \\
\hline No.6 & 15 回 & $93 \%$ \\
\hline No.7 & 15 回 & $100 \%$ \\
\hline No.8 & 15 回 & $73 \%$ \\
\hline No.9 & 15 回 & $100 \%$ \\
\hline No.10 & 15 回 & $93 \%$ \\
\hline No.11 & 15 回 & $86 \%$ \\
\hline No.12 & 15 回 & $100 \%$ \\
\hline No.13 & 15 回 & $100 \%$ \\
\hline No.14 & 15 回 & $93 \%$ \\
\hline No.15 & 15 回 & $93 \%$ \\
\hline Total & 225 回 & $94 \%$ \\
\hline
\end{tabular}

表 7 人数毎の識別率

Identification rate of each number of people.

\begin{tabular}{r|r|r|r}
\hline \hline 識別人数 & 識別正答率 & 識別人数 & 識別正答率 \\
\hline 15 人 & $96 \%$ & 23 人 & $94 \%$ \\
\hline 16 人 & $95 \%$ & 24 人 & $92 \%$ \\
\hline 17 人 & $91 \%$ & 25 人 & $91 \%$ \\
\hline 18 人 & $90 \%$ & 26 人 & $92 \%$ \\
\hline 19 人 & $93 \%$ & 27 人 & $91 \%$ \\
\hline 20 人 & $93 \%$ & 28 人 & $92 \%$ \\
\hline 21 人 & $92 \%$ & 29 人 & $92 \%$ \\
\hline 22 人 & $92 \%$ & 30 人 & $91 \%$ \\
\hline
\end{tabular}

表 8 既存手法と提案手法との比較結果 Result of comparing existing method with proposal method.

\begin{tabular}{c|r}
\hline 比較手法 & 識別正答率 \\
\hline 既存研究の手法 ${ }^{12)}$ & $90 \%$ \\
\hline 本研究の提案手法 & $94 \%$ \\
\hline
\end{tabular}


ることができない，そのため，精度が低下することが予想 されたが, 精度は表 6 に示すように全体として $94 \%$ の識別 精度となり，概ね良好な結果となった。しかし，一部のク ラスに㧧いて精度が著しく低下して扔り，全体の精度が低 下している。この原因としては, 識別精度の低いクラスの 入力データと教師データを比較すると, 人物の髪型が極端 に異なっていることや，撮影時期が異なることによる人物 の肌の色が異なっていることがわかった．この原因は, 教 師データを定期的に更新し，教師データのパターンや数を 增やすことで解決できると考えられる。

また, 本研究では, 動画像から自動的に顔画像を取得し ているため, 様々なサイズの画像が存在する。 その結果, 既 存の高次局所自己相関特徵では識別精度が低下した。しか し, 本研究では取得した顔画像から解像度の異なる顔画像 を生成し，それぞれの顔画像から取得した高次局所自己相 関特徵を利用して識別を行っているため, 解像度の影響を 受けなることなく, 識別を行うことができた，そのため，本 研究の提案手法は，本研究の目的である勤怠管理の撮影条 件に適切な手法であるといえる。そして，表７に示すよう に, 識別対象の人数が増加しても $90 \%$ 以上の高い精度を保 つ結果となった，勤怠管理は，一般的に会社内の部署や課 毎に行うことが多く, 中規模の会社では, 部署や課の所属 人数は 15 人 30 人前後であると考えられる.このことか ら, 本システムは, 勤急管理を行う上で識別対象の人数の 変化にも充分対応しているといえる。

さらに, 既存手法と提案手法との比較実験では, 表 8 か ら高次局所自己相関特徵と線形判別分析を組合せた手法よ り精度の高い結果となった，今回の撮影条件では，低解像 度の画像が識別対象に多く含まれる撮影条件のため, 解像 度の変化に対応した本研究の提案手法が有効であるという 結果となった。

\section{3 既存研究の撮影環境における個人識別の識別率}

本実験では，高次局所自己相関特徽と線形判別分析を組 合せた手法 ${ }^{12)}$ で想定している撮影環境において実証実験 を行った，実験内容としては，被写体がカメラに対して正 面を向いた状態でディジタルカメラを用いて撮影した静止 画像を入力データとし, 教師データとの比較を行うことに よって, 入力データの人物の識別を行う.

(1) 実験結果

本実験では, ディジタルカメラで撮影した正面顔画像を 使用して, 高次局所自己相関特徵と線形判別分析を組合せ た手法と本研究の提案手法と精度比較実験を行った．なお， 1 回の識別に 1 枚の正面顔凷像を使用し, 凷像を变えて 15 回実験を行い，その識別正答率を算出した。精度比較の実 験結果を表 9 に示す.

(2) 考察

比較精度実験の結果として, 表 9 に示すように, 高次局 所自己相関特徽と線形判別分析を組合せた手法が $91 \%$, 本 研究で考案した手法が $96 \%$ という結果となり, 両手法とも

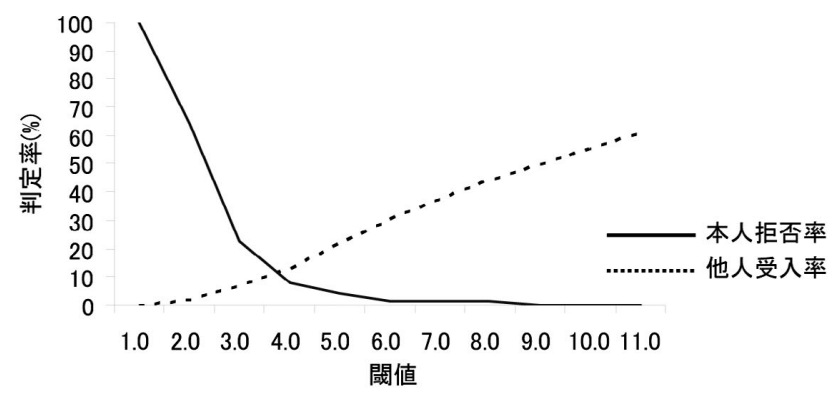

図 11 本人拒否率と他人受入率 FRR and FAR.

に本研究で想定している撮影環境での精度実験に比べ, 識 別精度が向上した．また，本研究で考案した手法は，高次 局所自己相関特徵と線形判別分析を組合せた手法と比べて, 同等以上の識別精度を得ることができた，そのため，既存 の個人識別で使用されている証明写真のような正面顔画像 が取得可能である場合, 本研究で考案した手法はさらに高 精度な識別が可能であると考えられる.ささらに, クラス毎 の精度比較に扔いても，ほぼすべてのクラスで同様もしく はそれ以上の精度を得ることができた。そのため, 既存研 究で想定している撮影環境に扔いて本研究で考案した手法 が有効であるといえる.

\section{4 本人拒否率と他人受入率}

本実験では，バイオメトリクス認証技術の評価手法によっ て本システムの有效性を実証する，バイオメトリクス認証 技術では, 認証の誤りは本人拒否率 (FRR:False Rejection Rate), 他人受入率 (FAR : False Acceptance Rate) の二 つの指標で評価される。これは個人識別に使用した闇值に より変化するが, 閾值を上げることで FRR は減少してい き, FAR は増加していく．この交差点での認証誤り率を交 差誤り率 (XER : Cross over Error Rate) と呼び, 評価の 指標として用いる.

\section{(1) 実験結果}

本研究で考案した手法の有効性を示すため, バイオメト リクス認証技術の評価手法を用いて実験を行った。個人識別 の際の閾値を変動させた場合の木人拒否率，他人受入率の 変化を図 11 に示す。なお，この曲線は，各クラスの FRR と FAR の結果の平均を示す.

(2) 考察

本実験では，FRR と FAR が等しくなる点の判定率 （XER）は 12 \%であった. バイオメトリクスを利用したセ キュリティシステムは，一般的に標準化された評価手法 $\left.{ }^{5} 20\right)$ が用意されており，それに従って精度の評価を行う。その

表 9 既存手法と提案手法との此較結果 Result of comparing existing method with proposal method.

\begin{tabular}{c|r}
\hline \hline 比較手法 & 識別正答率 \\
\hline 既存研究の手法 ${ }^{12)}$ & $91 \%$ \\
\hline 本研究の提案手法 & $96 \%$ \\
\hline
\end{tabular}


条件に従った場合，本研究の XER の結果は，あまり認証 精度の良い結果ではない。この原因としては, 本研究は被 写体に負担を与えないような撮影条件であり, 被写体の顔 画像の解像度は低く, 人物毎の顔の特徵の差異が少ないこ とが考えられる。また，実験デー夕の不足も原因の一つで あると考えられる. しかし, 同様に, 高次局所自己相関特 徵と線形判別分析を組合せた手法 ${ }^{12)}$ の XER を算出した結 果, $13 \%$ \%゙あったため, 高次局所白己相関特徴と線形判別 分析を組合せた手法に比べると, 本研究の提案手法の方が バイオメトリクス認証技術として有效であるといえる.

また，実用化を考えた場合，本研究では，認証ではなく 識別による勤总管理を目的としているため, 対象となる人 物が誰であるかを判定できればよい，また，他人と誤判定 しないことが最優先であるため, 個人識別に利用する閾值 は, XER の值より小さい值にする方が勤急管理に適して いるといえる.ただし, 撮影条件等の変化や光量変化等に より，本人と判定されない場合が発生することも考えられ， 他の手法と組合せることにより, よりロバストなシステム に改善する必要がある.

\section{5 評 価}

本実証実験では, 本研究で提案した手法が勤总管理の方 法として有効であるかを実証するため, 正面顔画像の判定の 精度検証, 本研究の撮影環境に扔ける個人識別の精度検証, 既存研究の撮影環境におる梳る個人識別の精度検証, バイオ メトリクス認証技術の評価手法である本人拒否率と他人受 入率の精度検証の四つの実験を行った。特に個人識別の精 度検証では, 本研究が想定している室内にディジタルビデ オカメラを設置した環境と既存研究が想定している被写体 の顔の高さにディジタルカメラを設置した環境おいて, 高 次局所自己相関特徵と線形判別分析を組み合わせた手法 ${ }^{12)}$ と本研究の提案手法との精度実験も行った.

正顔画像の判定の精度検証では, 表 5 に示すように, 正 面顔画像の判定率が $91 \%$ の結果を得ることができ, 動画像 巾から自動的に識別に利用可能な顔画像を取得できたとい える. また, 個人識別の精度検証では, 表 8 と表 9 に示す ように, 既存研究と本研究で想定している撮影環境の両方 で, 高次局所自己相関特徴と線形判別分析を組合せた手法 に比べて，4\%以上の精度を向上させることができた，そし て, 表 7 に示すように, 識別人数の増加に伴う識別率の推 移の比較では, 識別対象の人数が増加しても $90 \%$ 以上の精 度を保つことができ, 識別対象の人数が増加した場合にも 対応できると考えられる。 さらに, 本人拒否率と他人受入 率といったバイオメトリクス認証技術の評価基準に基づい て提案手法の有効性を実証した。

以上から, 本研究の提案手法は, 被写体がカメラを意識 することのない勤怠管理の手法として有効であるといえる. また，本システムの速度計測を行った．計測方法としては， 画像から正面顔画像を 30 枚使用し, 15 回の実験を行った. 計測結果としては, 計測速度の平均が 0.02 秒となった。 こ
のことから, 本システムは, 勤总管理システムとして充分 な速度であると考えられる。

\section{6. むすび}

本研究では, 顔画像の識別技術を用いて, 被写体が意識 することのない勤总管理の手法を提案した．室内にデイジ タルビデオカメラを設置し，個人識別を行った。 その結果, 従来のカメラを意識した認証とは異なり, 被写体がカメラ を意識することのない個人識別を実現した。そして，実証 実験では, 既存の最も精度の良い手法との比較実験を行う ことで, 本システムの有効性を実証した. 本システムでは, 識別精度が $94 \%$ という結果から，既存の手作業による勤怠 管理の手法と比較して, 従来の手作業によるミスがなくな ることやなりすましの防止が可能となると考元らる。し かし, 勤急管理を行うためには, $100 \%$ の精度が要求され る. 実環境では, 顔面像が正確に取得できない問題, 解像 度が異なる問題や輝度变化による問題等が発生する。その ため，実環境に扔ける個人識別の精度を $100 \%$ にすること は，現状ではほぼ不可能に近いと考えられる。そこで，今 後の課題として, 顔画像を用いた個人識別技術のみによる 勤怠管理ではなく, 他のアプローチからの勤总管理技術と 組合せることによって，より効率的で実用可能な勤急管理 システムの開発が挙げられる。

最後に, 本研究を遂行するにあたり, 文部科学省の平成 20 年度私立大学戦略的研究基盤形成支援事業「セキュアライ フ創出のための安全知循環ネットワークに関する研究」の 助成を受けた。ここに記して，感謝の意を表します。

\section{〔文献〕}

1）厚生労働省:“脳・心臓疾患及び精神障害等に係る労災補償状沉について”, 厚 牛労働省 (2008), http://www.mhlw.go.jp/houdou/2008/05/h05232.html

2）東京労働局：“労働時間・休日・休暇制度をめぐる状況”，東京労働局 (2002), http://roudoukyoku.go.jp/roudou/jikan/

3）村山憲治:“SPT: Simplifying Passenger Travel バイオメトリック認 証を用いた新しい航空手続き”, 情報処理, 47, 6, pp.583-588(2006)

4）日本自動認識システム協会編:“これでわかったバイオメトリクス”，オー 么社 (2001)

5）瀬戸洋一:“バイオメトリックセキュリテイ認証技術の動向と展望”, 情 報処理, 47, 6, pp.571-576(2006)

6）坂野鋭:“バイオメトリック個人認証技術の新展開”, 映情学技報, 26 , 22 , pp.25-32(2002)

7）赤松茂:“コンピュータによる顔の認識 -サーベイー”, 信学論, 80, 8, pp.2031-2046(1997)

8）佐藤 俊雄: “顔による個人認証”, 生体医工学：日本エム・イー学誌, 44 , 1, pp.40-46(2006)

9）岩井儀雄，勞世，山口修，平山高嗣：“画像処理による顔検出と顔認 識”, コンピュータビジョンとイメージメディア研究会研究報告, 2005, 38, pp.343-368(2005)

10) Brunelli, R. and Poggio, T. : Face recognition: Face recognition: features versus templates”, Pattern Analysis and Machine Intelligence, 15, 10, pp.1042-1052(1993)

11）内海ゆづ子, 岩井儀雄, 谷内田正彦:“顔認識のためのウェーブレット 特徽量の評価”, 知能と情報, 19, 5, pp.476-487(2007)

12) Goudail, F., Lange, E., Iwamoto, T., Kyuma, K.and Otsu, N.: "Fast face recognition method using high order autocorrelations", Proceedings of 1993 International Joint Conference on Neural Networks, 2, pp.1297-1300(1993)

13）ディシルバリヤナゲ，相澤清晴，羽鳥 光俊 :“人間の顔の向きの推定”, 電子情報通信学会パターン認識・理解研究会技術研究報告, 94, 101, pp.17-24(1994) 
14）大津展之:“判別および最小 2 乗規準に基づく自動しきい值選定法”，信 学論, 63, 4, pp.349-356(1980)

15）越智䈐，黑田英夫：“図解でわかる画像压維技術 JPEG\&MPEG”, 日本実業出版社 (1998)

16) Chai, D. and Ngan, K.N. : "Locating facial region of a headand-shoulders color image”, Proceedings of 1998 International Joint Conference on Automatic Face and Gesture Recognition, pp.124-129(1998)

17）小柳剛, 目加田慶人, 長谷川光司, 春日正男 : “正面・側面カメラ映像を 利用した人物正面顔の検出”，映情学技報，25，65，pp.19-24（2001）

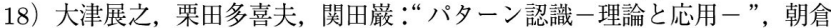
書店 (1996)

19）永田靖，棟近雅彦:“多変量解析法入門”，开イエンス社 (2001)

20）日本規格協会：“顔誌証システムの精度評価方法”，JIS 橴準情報 TS/TR X0086(2003)

21）瀬戸洋一，三村昌弘：“バイオメトリクス認証技術に扔ける精度評価の 動向”, 情報処理, 40, 11, pp.1099-1103(1999)

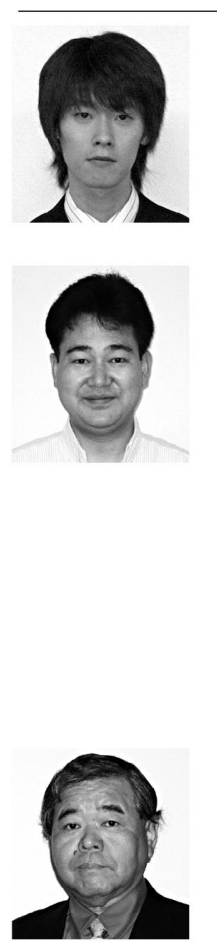

西笛義人 2005 年, 関西大学総合情報学部卒業. 2007 年, 関西大学大学院総合情報学研究科知識情報学専 攻博士課程前期課程修了. 現在, 関西大学大学院総合情厗 学研究科総合情報学専攻博士課程後期課程在学中. 修士 (情報学). 画像処理, CAD/CG 等の研究に従事. 2004 午. (株) 関西総合情報研究所入社.CAD システム，デー タモデル設計等の研究開発に従事.

态な伐典 1986 年, 関西大学工学部土木工学科 卒業. 1988 年, 関西大学大学院工学研究科土木工学専 攻博士課程前期課程修了. 同年, (株) 東洋情報システム （現在，TIS）に入社，知識情報処理システムに関する 研究受託開発業務に従事. 1994 年, 関西大学総合情報 学部専任講師. 1997 年, 助教授. 2004 年, 教授, 2006 年, 関西大学学生センター副所長, 現在に至る. 博士 (工 学). 2002 年 8 月から 1 年間カナダの UBC にて客員 助教授。専門は知識工学々土木情報学. 2000 年, (株) 関 西総合情報研究所を起業，設立当初から現在まで同社取 締役会長. 2006 年, (株) フォーラムエイトの顧問に就 任. CAD/CG, GIS/GPS, 画像処理, およびWeb ソ リューションビジネスに関連する研究業務に従事.また， ISO に準拠した $\mathrm{CAD}$ 製図基準と $\mathrm{CAD}$ デー夕交换基盤 の開発も従事.

古苦均 1971 年, 京都大学工学部卒業. 1973 年, 京都大学大学院工学研究科修士課程修了. 1976 年, 同大学院工学研究科博士課程修了. 同年, 京都大学工学 部助手，その後講師，助教授を経て，1994 年，関西大学 総合情報学部教授，現任に至る。博士 (工学)。その間, 米国パディー大学客員助教授, 米国プリンストン大学客 員研究員, 2004 年から 2005 年, 米国コロラド大学客員 教授. 構造物の信頼性解析，最適設計，ライフサイクル コスト解析, ソフトコンピューティングの構造設計・維 持管理への応用に関する研究に従事.

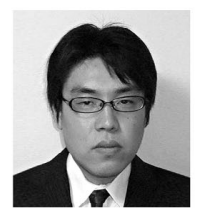

馬滒直登 2007 年, 関西大学総合情報学部卒業. 2009 年, 関西大学大学院総合情報学研究科知識情報学尃 攻博士課程前期課程修了．現在，富士フイルム株式会社， 修士 (情報学). 画像処理の研究に従事.

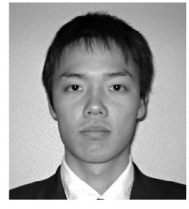

志化川洋平 2009 年, 関西大学総合情報学部卒業。 現在, 関西大学大学院総合情報学研究科知識情報学専攻 博士課程前期課程在学中. 画像処理の研究に従事.

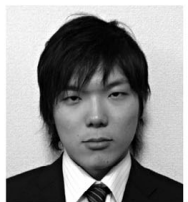

辛声尾 賢いち 2009 年, 関西大学総合情報学部卒業. 現在, 関西大学大学院総合情報学研究科知識情報学専攻 博士課程前期課程在学中. 画像処理の研究に従事. 